\title{
Temporal Genotypic Diversity of Schizaphis graminum (Rondani 1852) (Hemiptera: Aphididae) in a Black Oats (Avena strigosa) Field
}

\author{
Marcelo Lopes -da -Silva ${ }^{1 *}$ and Luiz Gonzaga Esteves Vieira ${ }^{2}$ \\ ${ }^{1}$ Laboratório de Quarentena Vegetal; Unidade Laboratorial de Entomologia; Núcleo Temático de Segurança \\ Biológica; Embrapa Recursos Genéticos e Biotecnologia; Av. W5 Norte (Final); 70770-917; Brasília - DF - Brasil. \\ ${ }^{2}$ Laboratório de Biotecnologia Vegetal; Instituto Agronômico do Paraná; Rod. Celso Garcia Cid; 86001-970; \\ Londrina - PR - Brasil
}

\begin{abstract}
The aim of this work was to analyze the clonal diversity variation in Schizaphis graminum during a complete phenological cycle of black oats (Avena strigosa). RAPD markers were used for detection of DNA polymorphisms of each clonal lineage, derived from a single clone collected weekly during a period of four months, in a crop field of black oats, Londrina, Paraná, Brazil. The monthly genotypic diversity was estimated by Shannon Information Index (H). Only four genotypes were distinguished from 122 specimens, with one of them overly predominant in all sampling dates (>60\%). Another genotype, apparently a later colonizer, rapidly reached greater frequency than other genotypes on the second and third month. The results of this work suggested that temporal genotypic diversity of S. graminum assessed by RAPD markers was small and less variable than the genetic variation found at geographical scale.
\end{abstract}

Key words: Genetic diversity, RAPD, temporal scale.

\section{INTRODUCTION}

Aphids are insects that have complex reproduction systems. They have sexual reproduction with fecundation and parthenogenesis, where females produce females, which are genetically identical. Parthogenetic reproduction is the only aphid reproduction system in many subtropical and tropical regions (Dixon, 1985). The lack of sexual recombination in parthenogenetic organisms leads to small or absence of genetic diversity. However, parthenogenetic populations of aphids retain genetic variation originated from mutations (Carvalho et al., 1991).

Cereals aphids are vectors of Barley Yellow Dwarf Viruses (BYDV) and Cereal Yellow Virus (CYDV) to wheat, barley, oats, and other several species of cultivated and wild grasses (Power and Gray, 1995). The elucidation of aphid movement pattern is important for the prediction of viruses spreading. Studies on aphids genotypic diversity at temporal scale may contribute to understand many aspects of their population dynamics; however, reports on this topic have shown controversial

*Author for correspondence: msilva@ cenargen.embrapa.br 
results. In some cases, no substantial modification of genotypic diversity at temporal scale in the same local could be observed (Shufran et al., 1991), while in others, there was significant variation (Guillemaud et al., 2003; Massonet and Weisser, 2004). These apparent disagreements could be attributable to the differences in sampling methodology, type of genetic markers, aphid species and environmental effects. For instance, Martinez-Torres et al. (1997) did not find genetic variation into populations of Rhopalosiphum padi (Linnaeus 1758) whereas Nicol et al. (1997) reported genetic variation at temporal scale in Metopolophium dirhodum (Walker 1849). The former authors utilized mitochondrial haplotypes for their study and the latter utilized RAPD markers. Microssatellites, which are considered one of the most efficient molecular marker to detect the genetic variation, allowed the detection of significant yearly differences in allele frequency of Sitobion avenae (Fabricius 1775) (English grain aphid) in the same area (Llewellyn et al., 2003).

The greenbug, Schizaphis graminum (Rondani 1852), is one of the most important cereal pests in the world. Defining biotypes as part of an aphid population that shares the same virulence to cultivated plants, several biotypes can be distinguished within populations of this aphid species (Lopes-da-Silva et al., 2004). S. graminum has been the target of research work aimed at understanding the biotypes evolution (Anstead et al., 2002), but despite the economic importance as a pest of cultivated grasses, aspects of its population dynamics have been neglected, mainly in South America.

Studies on genetic diversity at temporal scale may contribute to increase the knowledge on the migratory pattern of $S$. graminum in Brazil. Caetano (1973) proposed that wheat aphids migration was temporally affected according to the period of wheat cultivation. According to this hypothesis, in southern Brazil, the infestation of cereal crops arises mainly by the colonizers from northern regions, which implies in extinctions and recolonization events. As $S$. graminum populations have detectable genetic variation at geographic scale (Lopes-da-Silva et al., 2004), it could be assumed that high levels of aphid migration would result in temporal genetic variation locally. However, Lopes-da-Silva et al. (2004) considered that clones living on wild grasses nearby to cereals fields were the main colonizers, and most likely the sole colonizers at least in early stages of crop development.

In order to test the hypothesis that migration was the main variable that affected genetic diversity of $S$. graminum, in this work, RAPD molecular markers was used to evaluate the genetic diversity among $S$. graminum clones collected at same place within a complete phenological cycle of black oats as RAPD markers have been useful to detect genetic variability within and among the species of same genus (Crochemore et al., 2003).

\section{MATERIALS AND METHODS}

Clones of $S$. graminum were collected within a $2500 \mathrm{~m}^{2}(50 \mathrm{~m} \times 50 \mathrm{~m})$ area in a black oats field of approximately 3 ha located at the Instituto Agronômico do Paraná, IAPAR, Londrina, PR, Brazil (Latitude 2351'52" S, Longitude $\left.51^{\circ} 10^{\prime} 01^{\prime}, \mathrm{W}\right)$. Voucher specimens are deposited at Laboratório de Entomologia Agrícola, Universidade de Cruz Alta - UNICRUZ, Cruz Alta, RS, Brazil. The insects were collected one to three times every week, according with aphid abundance, from May to August, 2003. The size of the sampled area was defined arbitrarily based on the initial field infestation. Sampling was done at eight fixed points inside the chosen area, and each point consisted of a single one meter row inspected (15-25 plants/m). Preferentially, a single nymph was collected from the group of nymphs nearest to the parthenogenetic adult female. These nymphs were assumed to belong to the same clonal lineage of the adult female. Also, isolated aptera and alata females were collected only in the periods when the number of insects in the field was very small. A total of 164 clones were collected during the entire period. These clones were placed on the leaves of wheat seedlings cv. IAC-5-Maringá planted in the pots protected by transparent acrylic cylinders with the top covered with voil fabrics to avoid parasitism.

From each clone, a clonal lineage was multiplied, preserved in $95 \%$ ethanol and stored at $-20^{\circ} \mathrm{C}$ until DNA isolation. Genomic DNA was extracted according to Carvalho and Vieira (2001) with minor modifications. Five clones from each lineage were put into $1.5 \mathrm{ml}$ microcentrifuge tubes with $200 \mu \mathrm{L}$ extraction buffer $[200 \mathrm{mM}$ Tris-HCl ( $\mathrm{pH}$ 8.0), $2 \mathrm{M} \mathrm{NaCl}, 0.5 \mathrm{M}$ EDTA) and $50 \mu \mathrm{L}$ sarcosyl. The suspensions were left in a warmer 
plate at $65^{\circ} \mathrm{C}$ for $30 \mathrm{~min}$ and then submitted to centrifugation at $10,000 \mathrm{rpm}$ for $15 \mathrm{~min}$. The supernatant was recovered in microtubes, where $110 \mu \mathrm{L}$ ammonium acetate and $250 \mu \mathrm{L}$ isopropanol were added for DNA precipitation at $20^{\circ} \mathrm{C}$. After centrifugation $(10000 \mathrm{rpm})$ during 15 min, the supernatant was discarded and DNA pellet was washed with $70 \%$ ice-cold ethanol twice. The DNA re-suspension was done with 25 $\mu l$ TE Buffer (Tris-EDTA, pH 8.0) contained RNAase $(10 \mu \mathrm{g} / \mathrm{mL})$. DNA was stored at $-20{ }^{\circ} \mathrm{C}$.

The PCR-RAPD reactions were prepared in $0.6 \mathrm{ml}$ microtubes in a $25 \mu \mathrm{l}$ reaction volume containing reaction buffer $[20 \mathrm{mM}$ Tris $\mathrm{HCl}(\mathrm{pH} 8.4), 50 \mathrm{mM}$ $\mathrm{KCl}$ ], $3 \mathrm{mM} \mathrm{MgCl}, 100 \mu \mathrm{M}$ of each dNTP, $5 \mathrm{pmol}$ primer, 1.0 U Taq polymerase and 25-50 $\mathrm{ng}$ of DNA. The amplification was done in a PTC-100 thermal cycler (MJ Research) with the following PCR cycle program: $5 \mathrm{~min}$ at $94^{\circ} \mathrm{C}$ followed by 40 cycles of $1 \mathrm{~min}$ at $94^{\circ} \mathrm{C}, 1 \mathrm{~min} 30 \mathrm{~s}$ at $40^{\circ} \mathrm{C}$ e $2 \mathrm{~min}$ at $72^{\circ} \mathrm{C}$, with final extension of $5 \mathrm{~min}$ at $72^{\circ} \mathrm{C}$. The amplification products were run in $5 \mathrm{~V} / \mathrm{cm}$ agarose gel electrophoresis $(1.5 \%$ with $0.5 x$ Tris-BorateEDTA), staining with $0.5 \mu \mathrm{g} / \mathrm{ml}$ ethidium bromide. The gels were visualized and photographed with KODAK EDAS 120 system of image capture.

Initially, the randomly selected primers OPA-2, OPA-3, OPA-7, OPA-10, OPA-11, OPA-12, OPA-13, OPA-14 and OPC-2 (OPERON Technologies) in 10 samples collected in each month were tested. Two primers, OPA-2 (5'TGCCGAGCTG-3') and OPC-2 (5'GTGAGGCGTC-3'). Only the fragments that produced clear polymorphic bands and smaller than $2500 \mathrm{bp}$, reproducible in two or more gels, were considered in the analysis.

The genotypic diversity per month was calculated using Shannon Information Index (Lewontin, 1972), by the following formula: $\mathrm{H}=$ $\Sigma\left[\left(\mathrm{p}_{\mathrm{i}}\right)\left(\log _{\mathrm{n}} \mathrm{p}_{\mathrm{i}}\right)\right.$, where $\mathrm{p}_{\mathrm{i}}$ was the frequency of $i$ genotypes per month. Chi-square tests $\left(X^{2}\right)$ were done to test significance of frequency variation between the two more abundant genotypes.

To identify the biotypes present in the field at the end of the sampling period, a rapid bioassay for virulence was carried out using the lesion technique methodology described in Lopes-daSilva et al. (2004). Ten clonal lineages originated by the females collected in August were reared on wheat Embrapa-16, which had the cultivar Amigo in its genetic background (biotype C-resistant and biotype E-susceptible).

\section{RESULTS AND DISCUSSION}

From the total of 164 clones, 42 were discarded due to parasitism, fungal infection and innoculation failure. Thus, 122 clonal lineages were multiplied for molecular analysis (Table 1). Using only two primers (OPA-2 and OPC-2), it was possible to distinguish four genotypes among all clonal lineages analyzed, which were identified by the codes: $S g 1, S g 2, S g 3$ e $S g 4$ (Fig. 1A-D, Table 1, Table 2). In this work, even using fewer primers than Lopes-da-Silva et al (2004), it was possible to find in only one black oats field about $30 \%$ of the genetic diversity found for $S$. graminum collected in several regions of Brazil. Within Metopolophium dirhodum, Nicol et al. (1997), also using only two primers, distinguished five genotypes from 142 clones. In regions where sexual phase occurs, the genetic diversity of cereals aphids tends to be high even in small areas. For example, Lushai et al. (2002) discriminated 14 genotypes of Sitobion avenae among 216 clones using only one primer in a site in England. There is only one report of gamic morphs of $S$. graminum occurring at field condition in Brazil (Cabette, 1995). However, this seemed to be an uncommon phenomenon because no other reports or other descriptions were presented in the literature. In Brazil, the genetic variability in aphids has been found (Lopes-da-Silva et al., 2004; Lopes-da-Silva and Vieira, 2007); however, populations surveyed were collected from several cereal producing regions. Also, in this case the number of RAPD primers necessary to detect the polymorphism was greater than reported by other authors in studies carried out in other countries (Lushai et al., 2002; Figueroa et al., 2002). The results presented here clearly showed that the Brazilian S. graminum populations were more genetically structured at geographical scale when compared with other countries (Black et al., 1992; Shufran et al., 1991).

The RAPD profile obtained with the OPC-2 primer is similar to that obtained by Lopes-daSilva et al. (2004) for biotype E. The test for lesion qualification using the wheat cultivar EMBRAPA16 with ten clonal lineages at the end of the sampling period confirmed that the clonal lineages 
analyzed belonged to biotype $\mathrm{E}$. The presence of a single biotype in a crop, or, higher frequency of one biotype in a region was reported for $S$. graminum in United States (Shufran et al., 1991; Shufran et al., 1992; Peters et al., 1997), where biotype $\mathrm{E}$ has been considered the most common in wheat crops from the Great Prairies (Kansas,
Oklahoma, Missouri and part of Texas) (Peters et al., 1997). In Brazil, according to Lopes-da-Silva et al. (2004), the clones of biotype E were identified until 1998. During 1999-2000 surveys, biotype $\mathrm{E}$ was not found and, only in 2001 and 2002 surveys, biotype $\mathrm{E}$ were identified again.

Table 1 - Amount of clonal genotypes per month during May-August, 2003. IAPAR, Londrina, PR.

\begin{tabular}{|c|c|c|c|c|c|c|}
\hline \multirow{2}{*}{ Genotype } & \multicolumn{6}{|c|}{ Months } \\
\hline & May & June & July & August & Total & $\%$ \\
\hline$S g 1$ & 26 & 26 & 9 & 13 & 74 & 61.0 \\
\hline$S g 2$ & - & 23 & 13 & 4 & 40 & 32.5 \\
\hline$S g 3$ & - & 1 & - & - & 1 & 0.8 \\
\hline$S g 4$ & 5 & 1 & - & 1 & 7 & 5.7 \\
\hline Clones/month & 31 & 51 & 22 & 18 & 122 & 100.0 \\
\hline
\end{tabular}

Table 2 - Identification of S. graminum genotypes based on the presence/absence of polymorphic fragments produced by RAPD, using two primers $(b p=$ base pairs inferred by visual comparation with DNA Molecular Weight Ladder).

\begin{tabular}{ccc}
\hline Genotype & OPA-2 1000 bp & OPC-2 1100 bp \\
\hline$S g 1$ & + & + \\
$S g 2$ & - & + \\
$S g 3$ & - & + \\
$S g 4$ & - & + \\
\hline
\end{tabular}

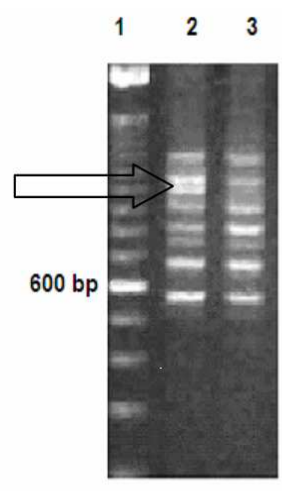

A

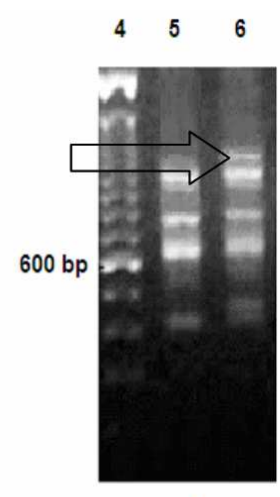

B

Figure 1 - Profiles of RAPD genotypes of S. graminum. A - 1, Ladder 100 bp with 600 bp. as indicator of DNA fragments size; 2, OPA-2 profile with arrow indicating the presence of $1000 \mathrm{bp}$ polymorphic fragment.; 3, OPA-2 profile with absence of $1000 \mathrm{bp}$ polymorphic fragment. B - 4, Ladder $100 \mathrm{bp}$; 5, OPC-2 profile with absence of 1100 bp polymorphic fragment; 6, OPC-2 profile with arrow indicating 1100 bp polymorphic fragment.

In this study, $S g 1$ genotype was dominant and present in all the months and in all samples, except in July when genotype $S g 2$ was more abundant. June was the month with the highest genotypic diversity given that all the four genotypes were detected. Also, the two most common genotypes, $\mathrm{Sg} 1$ and $\mathrm{Sg}$ 2, had very similar frequencies of occurrence in this month. No substantial differences in the proportion of each genotype present in the field were observed after June (Table 3). One of the hypotheses to explain the predominance of $\mathrm{Sgl}$ genotype was that this genotype was a pioneer colonizer that turned out to be abundant due to the low incidence of biological control agents in early stages of crop development. When aphid colonization is at the 
beginning, there is no significant parasitism and predation. As a consequence, the founder population will have predominance at temporal and spatial scale (Nicol et al., 1997; Nakashima and Akashi, 2005). The second most common genotype, $S g 2$, was only detected in the samples collected in June, but already detected with higher frequency at this month. However, no significant difference was found in $S g 1$ and $S g 2$ frequencies between June and July samples $\left(X^{2}=0.90, p=0.34\right.$, d.f. $=1)$. This suggested that the rapid increasing of $\mathrm{Sg} 2$ in June could be caused by a great dispersion movement of this genotype within the sampling area. Between July and August, $\mathrm{Sg} \mathrm{I}$ became again significantly more abundant than $\operatorname{Sg} 2\left(X^{2}=4,92, \mathrm{p}=0.04\right.$, d.f $\left.=1\right)$. Beside the dispersion movement, variation of frequency of the more abundant genotypes could be considered as a random event, caused by genetic drift (Guillemaud et al., 1997; Massonet and Weisser, 2004). As natural selection resulted in less genetic diversity at temporal scale (Guillemaud et al., 1997), the genetic drift could better explain the diminishing of $S g 2$ genotype in August as the genetic diversity $\left(\mathrm{H}_{\mathrm{m}}\right)$ was not substantially altered
(Table 3). The selection effect would only be responsible for maintaining the low frequency of $\mathrm{Sg} 3$ and $\mathrm{Sg} 4$ genotypes. The abundance of first genotype detetected $(\mathrm{Sgl})$ showed the importance of the founder event in aphid diversity on a temporal scale.

Results showed evidence that genetic diversity of S. graminum could be small and temporally stable in oat fields. These findings are compatible with the report that populations of $S$. graminum on oats are very small in comparison with $R$. padi (Ronquim et al. 2004). Taking in consideration the total genetic variation observed from several areas of Brazil (Lopes-da-Silva et al., 2004), it could be concluded that migration was not the most important source of genetic variability for $S$. graminum populations locally. In this work, new RAPD polymorphism were identified, with the presence of $1100 \mathrm{bp}$ fragment with OPC-2 primer. The quantification of genetic diversity at specific sites would be important for the $S$. graminum management because the control methods could provide the opportunity for emerging new phenotypes to overcome the difficult environmental conditions.

Table 3 - Diversity of $S$. graminum genotypes obtained by RAPD (May-August 2003) within a black oats (Avena strigosa cv. IAPAR 61 field in Londrina, Paraná. $\mathrm{H}_{\mathrm{m}}$ : Shannon Informative Index for Monthly Genetic Diversity. $\mathrm{Ht}$ : Shannon Informative Index for Total Genetic Diversity for the months. $\% \mathrm{H}_{\mathrm{m}} / \mathrm{Ht}$ : ratio between monthly genetic diversity and total genetic diversity.

\begin{tabular}{cccc}
\hline Month & $\mathbf{H}_{\mathbf{m}}$ & $\mathbf{H}_{\mathbf{t}}$ & $\mathbf{\%}_{\mathbf{m}} / \mathbf{H}_{\mathbf{t}}$ \\
\hline May & 0.441 & - & 50.7 \\
June & 0.857 & - & 98.6 \\
July & 0.857 & - & 77.1 \\
August & 0.730 & - & 84.0 \\
May-August & - & 0.869 & 100.0 \\
\hline
\end{tabular}

\section{ACKNOWLEDGEMENTS}

MLS is grateful to the CAPES for the research fellowship.

\section{RESUMO}

Os estudos de diversidade genética de afídeos em escala temporal podem contribuir para a compreensão dos padrões de migração e dispersão desse grupo de insetos. Este trabalho teve como objetivo quantificar a variação da diversidade clonal em Schizaphis graminum durante o ciclo fenológico da aveia-preta (Avena strigosa). Marcadores RAPD foram utilizados para detectar polimorfismos de DNA em cada linhagem clonal, originada de clones individualmente coletados semanalmente, durante um período de quatro meses, em um campo de aveia-preta, em Londrina, Paraná, Brasil. A diversidade genotípica mensal foi calculada através do índice de Informação de Shannon $(\mathrm{H})$. Apenas quatro genótipos puderam ser distinguidos, um dos quais foi predominante no total das coletas (>60\%). Outro genótipo, aparentemente um colonizador tardio, alcançou rapidamente uma elevada freqüência nas coletas do segundo e terceiro mês. Os resultados deste trabalho sugerem que a diversidade genotípica temporal de $S$. graminum na área de aveia-preta foi pequena e pouco variável em comparação com a variação genética geográfica. 


\section{REFERENCES}

Anstead, J.A.; Burdon, J.D.; Shufran, K.A. (2002), Mitochondrial DNA sequence divergence among Schizaphis graminum (Hemiptera: Aphididae) clones from cultivated and non-cultivated hosts: haplotype and host associations. Bull. Ent. Res., 92, 17-24.

Black IV, W.C.; DuTeau, N.M.; Puterka, G.J. ; Nechols ,J.R.; Pettorini, J.M. (1992), Use of random amplified polymorphic DNA polymerase chain reaction (RAPD-PCR) to detect DNA polymorphisms in aphids (Homoptera: Aphididae). Bull. Ent. Res. 82, 151-159

Cabette, H.S.R. (1995), Ocorrência de formas gâmicas e ambifásicas de Schizaphis graminum (Rondani) (Homoptera, Aphididae) em criações de campo e laboratório em São Paulo, Brasil. Revta. bras. Zool., 12, 655-662.

Caetano, V.R. (1973), Estudos sobre afídeos vetores do virus do nanismo Amarelo da Cevada, em especial de Acyrthosiphon dirhodum, em trigo no Sul do Brasil. Ph.D. Thesis, Universidade Estadual de Campinas, Campinas, Brazil

Carvalho, G.R.; Maclean, N.; Wratten, S.D.; Carter, R.E.; Thurston, J.P. (1991), Differentiation of aphid clones using DNA fingertrips from individual aphids. Proc. Biol. Sci., 243, 109-114.

Carvalho, A.O.R.; Vieira, L.G.E. (2001), Determinações das condições ótimas para análises de PCR-RAPD em Atta sexdens rubropilosa Forel (Hymenoptera: Formicidae). Neotrop. Entomol., 30, 593-600

Crochemore, M. L.; Molinari, H.B.C.; Vieira, L. G. E. (2003), Genetic diversity in passion fruit (Passiflora spp.) evaluated by RAPD markers. Braz. Arch. Biol. Tech., 46, 521-527.

Dixon, A.F.G. (1985), Structure of aphid populations. Ann. Rev. Entomol., 30, 155-174

Figueroa, C.C.; Loayza-Muro, R.; Niemeyer, H.M. (2002), Temporal variation of RAPD-PCR phenotype composition of the grain aphid Sitobion avenae (Hemiptera: Aphididae) on wheat: role of hydroxamic acids. Bull. Ent. Res., 92, 25-33.

Guillemaud, T.; Mieuzet, L.; Simon, J.C. (2003), Spatial and temporal genetic variability in French populations of the peach-potato aphid, Myzus persicae. Heredity, 91, 143-152.

Lewontin, R.C. (1972), The apportionment of human diversity. Evol. Biol., 6, 381-398.

Llewellyn, K.S; Loxdale, H.D.; Harrington, R; Brookes, C.P.; Clark, S.J.; Sunnucks, P. (2003), Migration and genetic structure of the grain aphid (Sitobion avenae) in Britain related to climatic adaptation and clonal fluctuation revealed using microsatellites. Mol. Ecol., 12, 21-34.

Lopes-da-Silva, M.;.Tonet, G.E.L; Vieira, L.G.E. (2004), Characterization and genetic relationships among Brazilian biotypes of Schizaphis graminum
(Rondani) (Hemiptera: Aphididae) using RAPD markers. Neotrop. Entomol., 33, 43-49.

Lopes-da-Silva, M.; Vieira, L.G.E. (2007), Analysis of Genetic Diversity of Metopolophium dirhodum Walker 1837 (Hemiptera:Aphididae) by RAPD markers. Rev. Bras. de Ent., 51, 54-57.

Lushai, G.; Markovitch, O; Loxdale, H.D. (2002), Hostbased genotype variation in insects revisited. Bull. Ent. Res. ,92, 159-164.

Martinez-Torres, D.; Moya, A.; Herbert, P.D.N. ; Simon, J.C. (1997), Geographic distribution and seasonal variation of mitochondrial DNA haplotypes in the aphid Rhopalosiphum padi (Hemiptera:Aphididae). Bull. Ent. Res., 87, 161-167. Massonet, B. and Weisser, W.W. (2004), Patterns of genetic differentation between populations of the specialized herbivore Macrosiphoniella tanacetaria (Homoptera, Aphididae). Heredity, 93, 577-584.

Nakashima, Y. and Akashi, M. (2005), Temporal and within-plant distribution of the parasitoid and predator complexes associated with Acyrthosiphon pisum and A. kondoi on alfafa in Japan. Appl. Ent. Zool., 40, 137-144

Nicol, D.; Armstrong, K.F.; Wratten, S.D.; Cameron, C.M.; Frampton, C.M.; Fenton, C.M.B. (1997), Genetic variation in an introduced aphid pest (Metopolophium dirhodum) in New Zealand and relation to individuals from Europe. Mol. Ecol., 6, 255-265.

Peters, D.C.; Ullah, F.; Karner, M.A.; Massey, W.B.; Mulder, P.G.; Beregovoy, V. H., (1997), Greenbug (Homoptera:Aphididae) biotype surveys in Oklahoma, 1991-1996. J. Kans. Entomol. Soc., 70, 120-128.

Power, A.G.; Gray, S. (1995), Aphid Transmission of Barley Yellow Dwarf Viruses: Interactions between Viruses, In-Barley Yellow Dwarf: 40 Years of Progress (C.J. D'Arcy and P. Burnett). The American Phytopalogical Society, St. Paul, pp 259-291.

Ronquim, J.C.; Pacheco, J. M.; Ronquim, C.C. (2004), Ocurrence and parasitism of aphids (Hemiptera: Aphididae) on cultivars of irrigated oat (Avena spp.) in São Carlos, Brazil. Braz. Arch. Biol. Technol., 47, 163-169.

Shufran, K.A.; Black IV, W.C.; Margolies, D.C. (1991), DNA fingerprinting to study spatial and temporal distributions of an aphid, Schizaphis graminum (Homoptera: Aphididae). Bull. Entomol. Res., 81, 303-313.

Shufran, K. A; Margolies, D.C; Black IV, W.C. (1992), Variation between biotype E clones of Schizaphis graminum (Homoptera: Aphididae). Bull. Ent. Res., 82, 407-416.

Received: January 17, 2008; Revised: November 11, 2009; Accepted: December 27, 2009. 